\title{
Calpain Activation in Alzheimer's Model Mice Is an Artifact of APP and Presenilin Overexpression
}

\author{
Takashi Saito, Yukio Matsuba, Naomi Yamazaki, Shoko Hashimoto, and ĐTakaomi C. Saido \\ Laboratory for Proteolytic Neuroscience, RIKEN Brain Science Institute, Wako 351-0198, Japan
}

Intraneuronal calcium stimulates the calpain-dependent conversion of $\mathrm{p} 35$ to $\mathrm{p} 25$, a CDK5 activator. It is widely believed that amyloid $\beta$ peptide $(\mathrm{A} \beta)$ induces this conversion that, in turn, has an essential role in Alzheimer's disease pathogenesis. However, in vivo studies on p25 generation used transgenic mice overexpressing mutant amyloid precursor protein (APP) and presenilin (PS). Here, using single App knock-in mice, we show that p25 generation is an artifact caused by membrane protein overexpression. We show that massive $\mathrm{A} \beta_{42}$ accumulation without overexpression of APP or presenilin does not produce p25, whereas p25 generation occurred with APP/PS overexpression and in postmortem mouse brain. We further support this finding using mice deficient for calpastatin, the sole calpain-specific inhibitor protein. Thus, the intracerebral environment of the APP/PS mouse brain and postmortem brain is an unphysiological state.

Key words: amyloid; calpain; $\mathrm{Na}_{\mathrm{v}} 1.1 ; \mathrm{p} 25$

\section{Significance Statement}

We recently estimated using single $A p p$ knock-in mice that accumulate amyloid $\beta$ peptide without transgene overexpression that $60 \%$ of the phenotypes observed in Alzheimer's model mice overexpressing mutant amyloid precursor protein (APP) or APP and presenilin are artifacts (Saito et al., 2014). The current study further supports this estimate by invalidating key results from papers that were published in Cell. These findings suggest that more than 3000 publications based on APP and APP/PS overexpression must be reevaluated.

\section{Introduction}

Since 1995 (Games et al., 1995), experimental AD research in cell and animal models has suffered from artifactual findings caused by protein overexpression paradigms (Nilsson et al., 2014; Saito et al., 2014). Membrane protein overexpression results in chronic ER stress that elevates cytoplasmic calcium concentrations (Chaudhari et al., 2014; Borkham-Kamphorst

Received June 14, 2016; revised July 8, 2016; accepted Aug. 5, 2016.

Author contributions: T.S., S.H., and T.C.S. designed research;T.S., Y.M., N.Y., and T.C.S. performed research; T.S., Y.M., N.Y., and T.C.S. contributed unpublished reagents/analytic tools; T.S., Y.M., N.Y., and T.C.S. analyzed data; T.C.S. wrote the paper.

This work was supported by a Grant-in-Aid for Scientific Research (B) from the Ministry of Education, Culture, Sports, Science and Technology of Japan (T.S.); the Japan Science and Technology Agency Precursory Research for Embryonic Science and Technology (T.S.); and the Brain Mapping by Integrated Neurotechnologies for Disease Studies project of the Japan Agency for Medical Research and Development (T.C.S.). We thank Kazuhiro Yamakawa for providing antibodies to $\mathrm{Na}_{\mathrm{v}} 1.1$ and Charles Yokoyama for editing this manuscript.

T.S., Y.M., and T.C.S. serve as advisor, director, and CEO, respectively, for RIKEN BIO Co. Ltd., a RIKEN venture based at the Brain Science Institute, Central Building, Wako, Japan.

This article is freely available online through the J Neurosci Author Open Choice option.

Correspondence should be addressed to Takaomi C. Saido at the above address. E-mail: saido@brain.riken.jp. DOI:10.1523/JNEUROSCI.1907-16.2016

Copyright $\odot 2016$ Saito et al.

This is an Open Access article distributed under the terms of the Creative Commons Attribution License Creative Commons Attribution 4.0 International, which permits unrestricted use, distribution and reproduction in any medium provided that the original work is properly attributed. et al., 2016). For instance, Seo et al. (2014) used transgenic mice that overexpressed APP and presenilin carrying 5 familial AD-associated mutations (5XFAD mice; Oakley et al., 2006). Although the two transgenes inserted impair at least two gene loci of the host animals, these and other transgenic mice have never been sequenced, to our knowledge. In this case, the asserted disease mechanisms were evidently studied without sufficient mouse genetic controls.

\section{Materials and Methods}

Mutant mice. App $p^{N L-F / N L-F}$ and calpastatin (Cast) KO mice were maintained as described previously (Saito et al., 2014). All the mice used in the experiments were male and established on a C57BL/6J background. All animal experiments were performed according to the RIKEN Brain Science Institute's guidelines for animal experimentation.

Western blot analysis. We prepared brain extracts from postmortem mouse brain excised at 1 or $2 \mathrm{~h}$ after demise as a positive control for calpain activation (Taniguchi et al., 2001). AD model mouse brains were prepared as described previously (Higuchi et al., 2005). We subjected the samples to Western blot analysis using anti-p35/25 antibody (C64B10, Cell Signaling Technology) and anti- $\beta$-tubulin antibody (SAP.4G5, Abcam).

We also analyzed the expression levels of $\mathrm{Na}_{\mathrm{v}} 1.1$. Brain extracts prepared as described previously (Ogiwara et al., 2013) were sub- 
jected to immunoblotting using rabbit antiC-terminal $\mathrm{Na}_{\mathrm{v}} 1.1$ (IO1; Ogiwara et al., 2007) and anti- $\beta$-tubulin antibody. Each set of experiments was repeated at least three times. The band intensity was determined with a densitometer (LAS4000, Fujifilm).

Statistical analysis. All data are shown as means \pm SEM. For comparisons among four groups, one-way ANOVA followed by post hoc test (Scheffe's $F$ test) was used, using Statcel 3 (add-in software on Microsoft Excel).

\section{Results}

We crossed APP-overexpressing mice with Cast $\mathrm{KO}$ mice and observed peculiar phenotypes (Higuchi et al., 2012), including early lethality, where half of the mice died in 10 weeks. This result contradicts the chronic, progressive nature of $\mathrm{AD}$. Conversely, when we crossed mutant humanized App knock-in mice, overproducing $\mathrm{A} \beta_{42}$ without overexpressing APP, with Cast $\mathrm{KO}$ mice, the double mutant mice lived as long as wild-type mice, or $>2$ years (Saito et al., 2014), indicating that the phenotype of early lethality was an overexpression artifact. More than 3000 papers have been published using these old generation APP mouse models, and we conclude that the results described in these papers require reevaluation using new generation models. As a first step, we examined $\mathrm{A} \beta$-induced calpaindependent p25 generation (Oakley et al., 2006; Seo et al., 2014), based on studies of the calpain-calpastatin system (Saido et al., 1994).

We confirmed conversion of p35 to p25 by calpain in postmortem mouse brain as a positive control (Taniguchi et al., 2001; Fig. 1, first through fourth lanes). This conversion is caused by intraneuronal ATP depletion resulting in an elevation of cellular calcium concentration (Lipton, 1999). We then examined aged 24-month-old $A p p^{N L-F / L-F}$ mice (Saito et al., 2014; Fig. 1, fifth and sixth lanes) and observed no conversion of p35 to $\mathrm{p} 25$ despite massive $\mathrm{A} \beta$ deposition (Saito et al., 2014). This finding disagrees with the results of Oakley et al. (2006) and Seo et al. (2014).

We crossed $A p p^{N L-F / N L-F}$ mice with Cast $\mathrm{KO}$ mice, in which calpain is hyperactivatable (Higuchi et al., 2005; Takano et al., 2005). Even in the absence of calpastatin, we saw no conversion of p35 to p25 (Fig. 1, seventh and eighth lanes) despite the observation that calpastatin deficiency increases $A \beta$ amyloidosis (Saito et al., 2014). Thus, we conclude that p 25 generation in 5XFAD mice is an artifact.
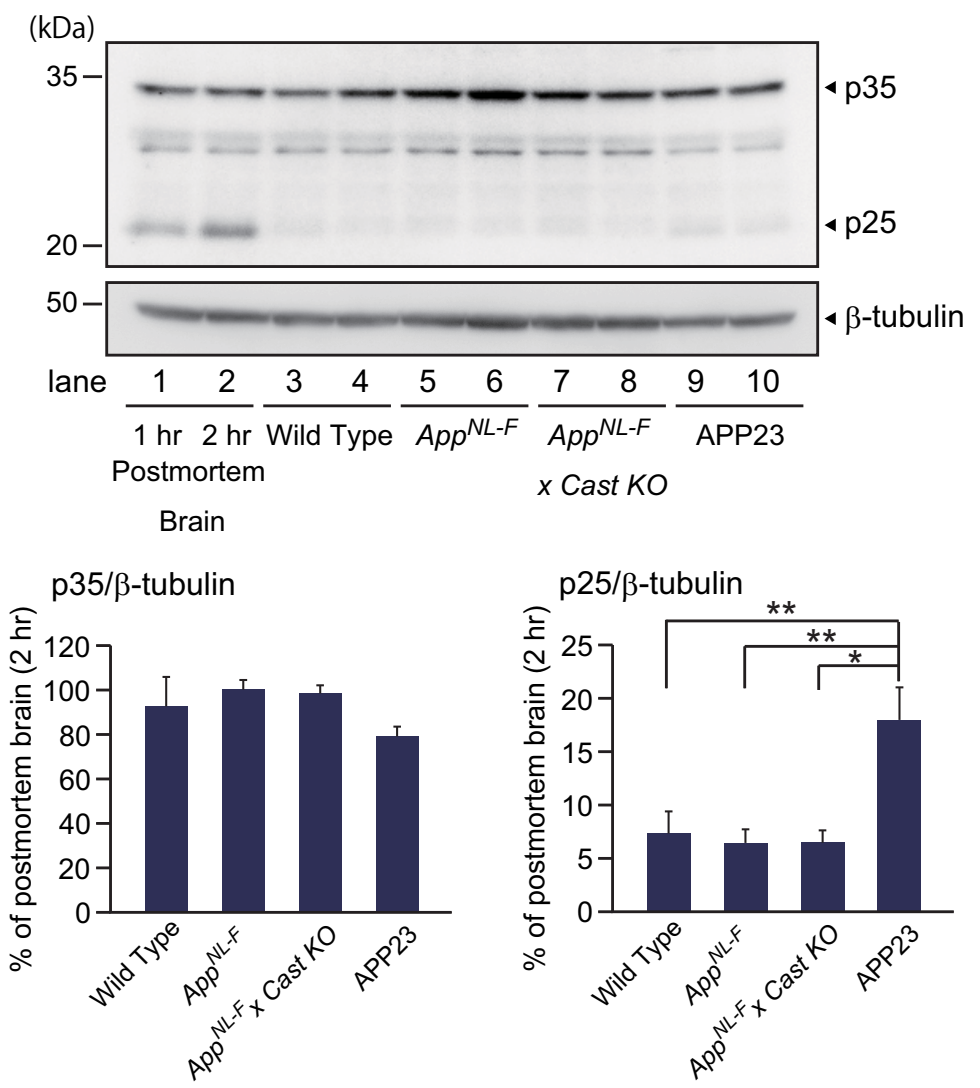

Figure 1. Generation of 25 in App knock-in and APP-overexpressing mice. We performed a Western blot analysis of wild-type postmortem brain, wild-type control brain, 24 month old $A p p^{N L-F / N L-F}$ brain, App $p^{N L-F / N L-F}$ X Cast KO brain, and APP-overexpressing (APP23) brain using antibodies to p35/p25 and to $\beta$-tubulin. The band intensities were quantified as shown in the graph $(n=4)$. ${ }^{*} p<0.05 ;{ }^{* *} p<0.01$ (one-way ANOVA, Scheffe's $F$ test). Data represent mean \pm SEM.

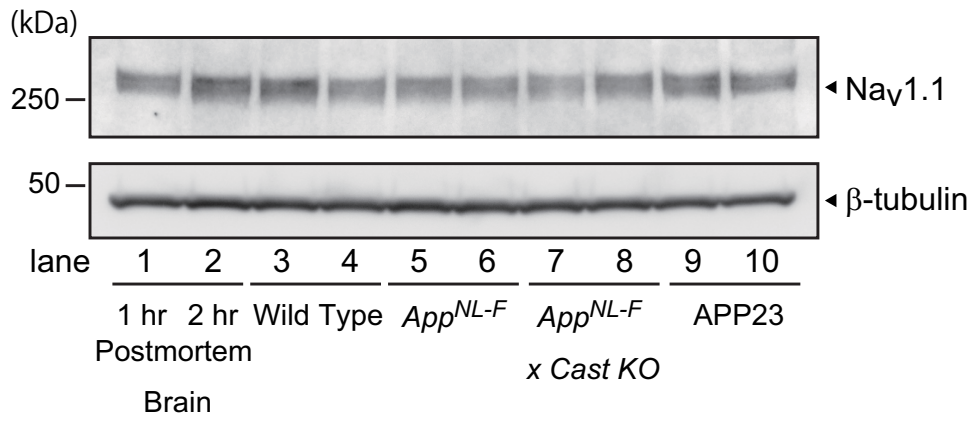

Nav1.1/ß-tubulin

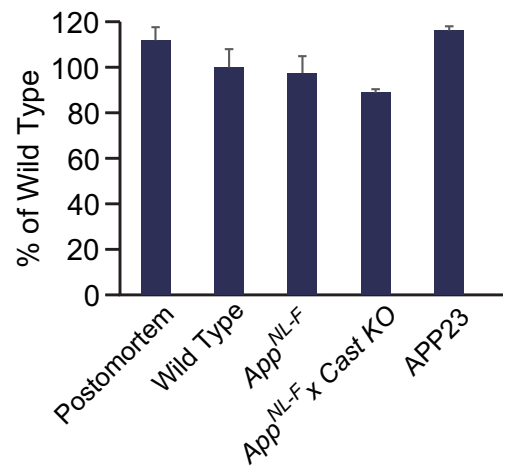

Figure 2. Expression levels of $\mathrm{Na}_{v} 1.1$ in App knock-in and APP-overexpressing mice. We performed a Western blot analysis of wild-type control brain, 24 month old $A p p^{N L-F / N L-F}$ brain, App ${ }^{N L-F / N L-F}$ X Cast KO brain, and APP-overexpressing (APP23) brain using antibodies to $\mathrm{Na}_{\mathrm{v}} 1.1$ and to $\beta$-tubulin. The band intensities were quantified as shown in the graph $(n=4)$. Data represent mean \pm SEM. 
Consistently, we observed p25 generation in APP23 mice that overexpress APP (Fig. 1, ninth and tenth lanes, bottom).

Protein overexpression paradigms are risky in biological science particularly with membrane proteins. In this regard, APP and PS possess one and nine transmembrane domains, respectively (Chen, 2015). In contrast, overexpression of mutant tau, a cytosolic protein, exhibited no effect on p25 levels (data not shown). Membrane protein overexpression results in chronic ER stress that elevates cytoplasmic calcium concentration (Chaudhari et al., 2014; Borkham-Kamphorst et al., 2016). This nonspecific calcium rise probably activates calpain, resulting in p25 generation in 5XFAD mice (Oakley et al., 2006; Seo et al., 2014). Likewise, 5XFAD mice exhibit intraneuronal $\mathrm{A} \beta$ that is supposed to cause neurodegeneration (Oakley et al., 2006). Indeed, when we crossed APPoverexpressing mice with Atg-7 KO mice lacking autophagy, we observed intraneuronal $\mathrm{A} \beta$ and enhanced neurodegeneration (Nilsson et al., 2013). However, autophagy deficiency, which induced intraneuronal $\mathrm{A} \beta$ accumulation in single $A p p$ knock-in mice, caused no neurodegeneration (unpublished data).

The overexpression paradigm may also explain the epileptic phenotypes of APP-overexpressing mice, which show a downregulation of $\mathrm{Na}_{\mathrm{v}} 1.1$, a sodium channel expressed in PV-positive interneurons (Verret et al., 2012), because $\mathrm{Na}_{\mathrm{v}} 1.1$ may also be another substrate of calpain (Ebensperger et al., 2005). Conversely, we observed no changes in $\mathrm{Na}_{\mathrm{v}} 1.1$ levels in App knock-in, APP-overexpressing, or postmortem brains (Fig. 2), suggesting that $\mathrm{Na}_{\mathrm{v}} 1.1$ downregulation is a phenomenon unique to the J-20 model mice.

\section{Discussion}

Of the five phenotypes that we observed in APP-overexpressing mice crossbred with Cast KO mice (Higuchi et al., 2012), only two were reproduced using single App knock-in mice crossbred with Cast KO mice (Saito et al., 2014). This result allows an estimation that $\sim 60 \%$ of the phenotypes observed using APPoverexpressing mice may be artifacts. We emphasize that both basic and clinical research communities must accept and remit this reality for the reasons outlined below.

All APP-overexpressing mice overproduce an APP fragment generated by $\beta$-secretase [C-terminal fragment $\beta$ (CTF$\beta$ ); Saito et al., 2014, their Supplemental Fig. 4a], which does not accumulate in the AD brain (Nilsson et al., 2014). CTF- $\beta$ is more neurotoxic than $\mathrm{A} \beta$ (Mitani et al., 2012). To our knowledge, almost all therapeutic anti- $\mathrm{A} \beta$ antibodies bind to CTF- $\beta$ because A $\beta$ and CTF- $\beta$ share common epitopes near the amino terminus or midregion of the $\mathrm{A} \beta$ sequence (Lannfelt et al., 2014). Therefore, the experimental passive immunization of APP-overexpressing mice may have improved cognitive function by removing CTF- $\beta$ rather than $A \beta$. If this proves true, the immunotherapeutic prevention trials conducted on thousands of human volunteers may not provide clear information about its beneficial effect. Alternatively, therapeutic antibodies may have bound to vascular amyloid in humans because immunotherapy marginally reduced $A \beta$ burdens only in apolipoprotein E4 genotype carriers (Salloway et al., 2014), where apolipoprotein E4 genotype is an independent risk factor for cerebral amyloid angiopathy (Shinohara et al., 2016).

In addition, essentially all candidate medications that failed in clinical trials (Mangialasche et al., 2010) have depended on old generation models for preclinical studies. Therefore, we suggest that a careful revalidation of all the results of scientific and clinical importance obtained using APP-overexpressing mice are urgently required. Depending on expression levels, not all AD model mice may produce artificial phenotypes. In this context, p25 generation can be one criterion in the reevaluation.

\section{References}

Borkham-Kamphorst E, Steffen BT, Van de Leur E, Haas U, Tihaa L, Friedman SL, Weiskirchen R (2016) CCN1/CYR61 overexpression in hepatic stellate cells induces ER stress-related apoptosis. Cell Signal 28:34-42. CrossRef Medline

Chaudhari N, Talwar P, Parimisetty A, Lefebvre d'Hellencourt C, Ravanan P (2014) A molecular web: endoplasmic reticulum stress, inflammation, and oxidative stress. Front Cell Neurosci 8:213. Medline

Chen M (2015) The maze of APP processing in Alzheimer's disease: where did we go wrong in reasoning? Front Cell Neurosci: 9:186. CrossRef

Ebensperger G, Ebensperger R, Herrera EA, Riquelme RA, Sanhueza EM, Lesage F, Marengo JJ, Tejo RI, Llanos AJ, Reyes RV (2005) Fetal brain hypometabolism during prolonged hypoxaemia in the llama. J Physiol 567:963-975. CrossRef

Games D, Adams D, Alessandrini R, Barbour R, Berthelette P, Blackwell C, Carr T, Clemens J, Donaldson T, Gillespie F, et al. (1995) Alzheimertype neuropathology in transgenic mice overexpressing V717F $\beta$-amyloid precursor protein. Nature 373:523-527. CrossRef Medline

Higuchi M, Tomioka M, Takano J, Shirotani K, Iwata N, Masumoto H, Maki M, Itohara S, Saido TC (2005) Distinct mechanistic roles of calpain and caspase activation in neurodegeneration as revealed in mice overexpressing their specific inhibitors. J Biol Chem 280:15229-15237. CrossRef Medline

Higuchi M, Iwata N, Matsuba Y, Takano J, Suemoto T, Maeda J, Ji B, Ono M, Staufenbiel M, Suhara T, Saido TC (2012) Mechanistic involvement of the calpain-calpastatin system in Alzheimer neuropathology. FASEB J 26:1204-1217. CrossRef Medline

Lannfelt L, Relkin NR, Siemers ER (2014) Amyloid- $\beta$-directed immunotherapy for Alzheimer's disease. J Intern Med 275:284-295. CrossRef Medline

Lipton P (1999) Ischemic cell death in brain neurons. Physiol Rev 79: 1431-1568. Medline

Mangialasche F, Solomon A, Winblad B, Mecocci P, Kivipelto M (2010) Alzheimer's disease: clinical trials and drug development. Lancet Neurol 9:702-716. CrossRef Medline

Mitani Y, Yarimizu J, Saita K, Uchino H, Akashiba H, Shitaka Y, Ni K, Matsuoka N (2012) Differential effects between $\gamma$-secretase inhibitors and modulators on cognitive function in amyloid precursor proteintransgenic and nontransgenic mice. J Neurosci 32:2037-2050. CrossRef Medline

Nilsson P, Loganathan K, Sekiguchi M, Matsuba Y, Hui K, Tsubuki S, Tanaka M, Iwata N, Saito T, Saido TC (2013) A $\beta$ secretion and plaque formation depend on autophagy. Cell Rep 5:61-69. CrossRef Medline

Nilsson P, Saito T, Saido TC (2014) New mouse model of Alzheimer's. ACS Chem Neurosci 5:499-502. CrossRef

Oakley H, Cole SL, Logan S, Maus E, Shao P, Craft J, Guillozet-Bongaarts A, Ohno M, Disterhoft J, Van Eldik L, Berry R, Vassar R (2006) Intraneuronal $\beta$-amyloid aggregates, neurodegeneration, and neuron loss in transgenic mice with five familial Alzheimer's disease mutations: potential factors in amyloid plaque formation. J Neurosci 26:10129-10140. CrossRef Medline

Ogiwara I, Miyamoto H, Morita N, Atapour N, Mazaki E, Inoue I, Takeuchi T, Itohara S, Yanagawa Y, Obata K, Furuichi T, Hensch TK, Yamakawa K (2007) $\mathrm{Na}_{\mathrm{v}} 1.1$ localizes to axon of parvalbumin-positive inhibitory interneurons: a circuit basis for epileptic seizures in mice carrying an Scnla gene mutation. J Neurosci 27:5903-5914. CrossRef Medline

Ogiwara I, Iwasato T, Miyamoto H, Iwata R, Yamagata T, Mazaki E, Yanagawa Y, Tamamaki N, Hensch TK, Itohara S, Yamakawa K (2013) $\mathrm{Na}_{\mathrm{v}} 1.1$ haploinsufficiency in excitatory neurons ameliorates seizureassociated sudden death in a mouse model of Dravet syndrome. Hum Mol Genet 22:4784-4804. CrossRef Medline

Saido TC, Sorimachi H, Suzuki K (1994) Calpain: new perspectives in molecular diversity and physiological-pathological involvement. FASEB J 8:814-822. Medline 
Saito T, Matsuba Y, Mihira N, Takano J, Nilsson P, Itohara S, Iwata N, Saido TC (2014) Single App knock-in mouse models of Alzheimer's disease. Nat Neurosci 217:661-663. CrossRef

Salloway S, Sperling R, Fox NC, Blennow K, Klunk W, Raskind M, Sabbagh M, Honig LS, Porsteinsson AP, Ferris S, Reichert M, Ketter N, Nejadnik B, Guenzler V, Miloslavsky M, Wang D, Lu Y, Lull J, Tudor IC, Liu E, et al. (2014) Two phase 3 trials of bapineuzumab in mild-to-moderate Alzheimer's disease. N Engl J Med 370:322-333. CrossRef Medline

Seo J, Giusti-Rodríguez P, Zhou Y, Rudenko A, Cho S, Ota KT, Park C, Patzke H, Madabhushi R, Pan L, Mungenast AE, Guan JS, Delalle I, Tsai LH (2014) Activity-dependent p25 generation regulates synaptic plasticity and A $\beta$ induced cognitive impairment. Cell 157:486-498. CrossRef Medline

Shinohara M, Murray ME, Frank RD, Shinohara M, DeTure M, Yamazaki Y, Tachibana M, Atagi Y, Davis MD, Liu CC, Zhao N, Painter MM, Petersen RC, Fryer JD, Crook JE, Dickson DW, Bu G, Kanekiyo T (2016) Impact of sex and APOE4 on cerebral amyloid angiopathy in Alzheimer's disease. Acta Neuropathol 132:225-234. CrossRef Medline

Takano J, Tomioka M, Tsubuki S, Higuchi M, Iwata N, Itohara S, Maki M, Saido TC (2005) Calpain mediates excitotoxic DNA fragmentation via mitochondrial pathways in adult brains: evidence from calpastatin mutant mice. J Biol Chem 280:16175-16184. CrossRef Medline

Taniguchi S, Fujita Y, Hayashi S, Kakita A, Takahashi H, Murayama S, Saido TC, Hisanaga S, Iwatsubo T, Hasegawa M (2001) Calpain-mediated degradation of $\mathrm{p} 35$ to $\mathrm{p} 25$ in postmortem human and rat brains. FEBS Lett 489:46-50. CrossRef Medline

Verret L, Mann EO, Hang GB, Barth AM, Cobos I, Ho K, Devidze N, Masliah E, Kreitzer AC, Mody I, Mucke L, Palop JJ (2012) Inhibitory interneuron deficit links altered network activity and cognitive dysfunction in Alzheimer model. Cell 149:708-721. CrossRef Medline 